九州大学学術情報リポジトリ

Kyushu University Institutional Repository

\title{
Impact of Expression of Vimentin and AxL in Breast Cancer
}

\author{
田中，仁寛
}

ht tp://hdl. hand le. net/2324/1806850

出版情報 : 九州大学，2016，博士（医学），課程博士 バージョン：

権利関係：やむを得ない事由により本文ファイル非公開（2） 
論 文 名：Impact of Expression of Vimentin and Axl in Breast Cancer

（乳癌におけるVimentin と Axl 発現の臨床的意義）

区 分：甲

\section{論 文 内容の要旨}

【背景】受容体型チロシンキナーゼである Axl は 140kDa の蛋白であり、TAM (Tyro3, Axl, Mer) family のメンバーであり、乳癌を含めた様々な癌に発現する。先行研究に て、我々はvimentin蛋白発現症例が、トリプルネガティブ乳癌 (triple negative breast cancer: TNBC）において有意に予後不良であることを示した。Axl は上皮間葉系移行 の下流の作動因子であり、vimentin よよって制御されることが、前臨床のモデルで 報告されている。Axl 発現とvimentin 発現の関連は、いくつかの乳癌細胞株で報告 されている。しかしながら、乳癌組織におけるAxl 発現とvimentin 発現の臨床的意 義は完全には解明されていない。

【目的】原発性乳癌組織におけるAxlの発現を解析し、vimentinの発現との関連、 および臨床的意義を明らかにする。

【対象と方法】2003 年 1 月から 2010 年 12 月に九州大学消化器 ・総合外科にて手術 を施行した原発性乳癌（浸潤性乳管癌）343 例を対象とした。Stage I から III を含め、 術前化学療法あるいは術前内分泌療法症例や組織学的特殊型症例は除外した。Ax1 発現とvimentin 発現を免疫組織化学染色にて評価し、Axl 発現と臨床病理学的因子、 予後、vimentin 発現との関連を解析した。

【結果】 Axl 発現は、高発現群（170 例）と低発現群（173 例）に分類された。Axl 発現は、臨床病理学的因子や予後と相関を認めなかった。サブタイプ別の解析でも Axl 発現は予後と相関を認めなかった。TNBCの再発症例（5例）において、Ax1 高 発現群は全例再発後 2 年以内に死亡していた。

Vimentin 陽性かつ Axl 高発現腫瘍は、全乳癌の $10.5 \%$ （36 例）に認めた。Vimentin 陽性/ Axl 高発現腫瘍をvimentin 陽性/ Axl 低発現腫瘍、vimentin 陰性/ Axl 高発現腫瘍、vimentin 陰性/ Axl 低発現腫瘍を含む “その他群” と比較した。Vimentin陽性/ Axl 高発現腫 瘍は、TNBCと有意な相関を認めた $(\mathrm{P}=0.0396)$ 。Vimentin 陽性/ Axl 高発現群は、無 再発生存率（recurrence-free survival: RFS, P =0.0126）、全生存率（overall survival: $\mathrm{OS}, \mathrm{P}=0.0005)$ ともに“その他群” と比べ有意に予後不良であった（図）。多変量 解析では、vimentin 陽性/Axl 高発現は、RFS (ハザード比 hazard ratio: HR 2.78, 95\% 信頼区間 confidence interval：CI 1.23-5.68, P = 0.0158)および OS (HR 3.72, $95 \%$ CI 1.51-8.47, P = 0.0059)に対する独立した予後不良因子であった。サブタイプ別の解析 では、HER2 陽性乳癌と TNBCにおいて、vimentin 陽性/ Axl 高発現群は、全生存率 の有意な低下を認めた（ $\mathrm{P}=0.0298, \mathrm{P}=0.0194 ） 。$ 
無再発生存率

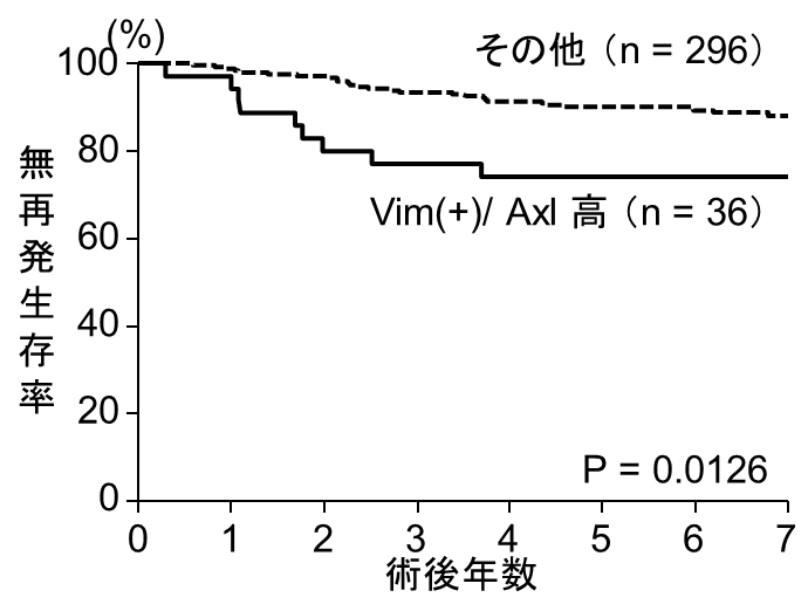

全生存率

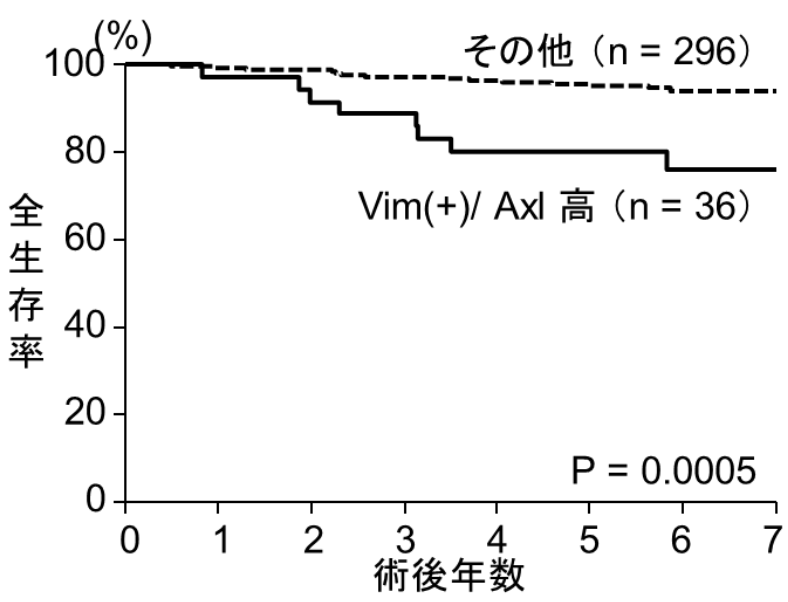

図：Vimentin/Axl 発現と予後との関連

【結語】Vimentin 陽性かつAxl 高発現は、原発性乳癌における予後不良因子である。 乳癌臨床検体においてvimentin 発現とAxl 発現を調べることは、乳癌患者における 予後不良群の予測に有用である。 
